\title{
Car Leasing in Lebanon from the Perspective of the Lessor
}

\author{
Samih Antoine Azar \\ Faculty of Business Administration \& Economics, Haigazian University \\ Mexique Street, Kantari, Beirut, Lebanon \\ E-mail: samih.azar@haigazian.edu.lb \\ Rana Obeid \\ Faculty of Business Administration \& Economics, Haigazian University \\ Mexique Street, Kantari, Beirut, Lebanon
}

Received: June 13, 2017 Accepted: July 6, 2017 Published: July 17, 2017

doi:10.5296/csbm.v4i2.11389 URL: http://dx.doi.org/10.5296/csbm.v4i2.11389

\begin{abstract}
This is a theoretical case study on car leasing in Lebanon from the perspective of the lessor. Although the methodology can be applied elsewhere we chose to take into consideration local domestic features. The procedure adopted is to start from a base model and then change the parameters of the model with the use of the command Data Table in Excel. We are able to conclude that car leasing can be a very profitable business even with modest input characteristics. The two factors that are highly relevant are the credit or financing limit, and the market salvage value, that both are critical to the lessor. We therefore recommend that car leasing firms pay particular attention on the natural depreciation of the car, choose, if possible, the customers with a good driving record, and equip the car with enhanced security measures. Alternatively the lessor can buy "full-risk" insurance against all damages to the car. This will help in mitigating the agency costs and the concomitant moral hazard that arise from the separation of ownership and control. Additionally the car leasing firm should aim to raise as much as possible its own borrowing capacity by appealing to its relative advantage from the pooling effect of holding a fleet of cars. Other factors, like, lending, or leasing rates, and borrowing rates, taxes, the recovery amount of the car, the car purchase price, and the assumed ROE have little effects.
\end{abstract}

Keywords: Case Study, Car Leasing, Lessor, Lebanon, Valuation Exercise 


\section{Introduction}

The purpose of this case study is to develop a financial framework for car leasing firms, or investors interested in such a field, in order to properly value a car leasing venture. Therefore it is a valuation exercise that is based upon the actual Lebanese legal, regulatory, and financing strictures. The perspective is from the side of the lessor. This is particularly interesting because the bulk of the academic literature studies leasing from the perspective of the lessee (see for example the recent paper by Dogan, 2016). The importance of this study is paramount because it will show that car leasing may be a golden egg if appropriate policy actions are taken. Although theoretically the framework is applicable to a firm located in Lebanon the study can be easily adapted to foreign countries.

In Lebanon car leasing by private resident citizens is scant. Most leases are intended to non-residents, or expatriates, on a trip or a visit to Lebanon, and, consequently are to be considered operating leases. Nonetheless the major assumption of the model is that the lease will last for three years. This will enable car leasing firms to engage in another and different endeavor, like that of medium term leasing. Effectively the mean duration of the lease is 3.6 years in Germany (Räthke-Döppner, 2013). The choice of a term of three years is dictated by local authorities who require that the leased car be at most three years old, and that the operating lease is for a maximum of three years.

The paper is organized as follows. In the next section, section 2, a briefing on the literature of concern is provided. In section 3 the results of the survey, which was carried out, is detailed. In section 4 all the cash flows pertinent to the lessor are identified. Section 5 covers the sensitivity analyses. The final section concludes.

\section{Briefing}

The advantages of car leasing to the lessees are many. They will pay for vehicle depreciation rather than the total cost of the vehicle (Mannering et al., 2002) since title to the car remains with the lessor. Moreover they will obtain the opportunity to have state of the art cars without buying the car, something that Mannering et al. (2002) call life cycle upgrading to a higher-quality vehicle. Leasing can relax the borrowing constraints of the lessee, whether it is another firm (Cosci et al., 2015), a smaller or growing firm (Lasfer \& Levis, 1998; Neuberger \& Räthke-Döppner, 2013; Dogan, 2016) or another individual. Incidentally the notion that leasing increases debt capacity, while generally espoused by practitioners, has been considered in the textbooks of corporate finance as a fallacy (Copeland \& Weston, 1992; Copeland et al., 2005; Ross et al., 2010; Brealey et al., 2014).

Other considerations for leasing from the perspective of the lessor are the following. First there is the tax effects if the lessor is in a higher tax bracket than the lessee or otherwise if the lessee does not have enough income to benefit from the tax shield of depreciation. This reason is the only one preferred by theoreticians, and its history goes back to the irrelevance theorems of Modigliani \& Miller (1958). Secondly, if the lessor has market power or has a comparative advantage in asset disposal (Lasper \& Levis, 1998), and if bankruptcy laws favor repossessions in a lease over disposal of assets in bankruptcy proceedings (Eisfeldt \& 


\section{Macrothink

Rampini, 2008). In this regard the paper by Smith \& Wakeman (1985) on the determinants of leasing policy remains relevant despite the passage of time. Finally it is unclear whether leasing and borrowing to purchase are substitutes or complements. Ang \& Peterson (1984) find surprising evidence for complementarity, which was contradicted later by Yan (2006).

Briefly, car leasing, as it is understood here, is about a leveraged operating lease. The lessor leases the car to the client for a period of three years and posts the car as collateral to finance its purchase. When the internal rate of return is higher than the target discount rate, leveraging acquires substantial benefits. It will be shown later that the major parameter of interest is how much debt is raised to finance the purchase of the car. Other parameters have muted effects.

\section{Survey Results}

A questionnaire was used to obtain answers to our research, or decision, variables which are to be used in our simulation:

a) The one-year required ROE (Return on Equity)

b) The lending or leasing rate (the interest rate charged to the lessee by the lessor)

c) The lending amount (the percentage of the car that the lessor chooses to be leased)

d) The borrowing rate (the rate on the financing of the lessor by the bank or lending firm).

e) The annual depreciation rate

f) The upper limit of the loan granted to the lessor, or credit limit, or even debt limit

The questionnaire was developed from scratch as the literature review did not show any related questionnaires that could be used to satisfy the objectives of this research. However to ensure the relevance of the questionnaire, it was pilot-tested with a leasing expert to ensure the clarity of the questions and their relevance. The pre-testing helped adjust the wording and format of some questions.

This research is subject to some limitations. First, it was difficult to check the accuracy of the responses given by the respondents. This issue is common to questionnaire-based studies where it is assumed that respondents usually provide accurate and honest answers. The second limitation was the lack of co-operation by 3 out of the 11 rental firms that offer car leasing in Lebanon. This affected the sample size and the collection of a broader expert opinion. Nonetheless we will use this survey and its results as a basis to our simulation (Table 1). 
Table 1. Survey results

\begin{tabular}{|l|l|l|l|l|l|}
\hline $\begin{array}{l}\text { ROE } \\
(\%)\end{array}$ & $\begin{array}{l}\text { Leasing Rate } \\
(\%)\end{array}$ & $\begin{array}{l}\text { Lending } \\
\text { Amount (\%) }\end{array}$ & $\begin{array}{l}\text { Borrowing } \\
\text { Rate (\%) }\end{array}$ & $\begin{array}{l}\text { Depreciation } \\
(\%)\end{array}$ & $\begin{array}{l}\text { Banking } \\
\text { Credit Limit (\%) }\end{array}$ \\
\hline 18 & 9 & 80 & 8 & 15 & 80 \\
16 & 9 & 60 & 5.5 & 18 & 80 \\
20 & 10 & 70 & 8 & 18 & 80 \\
20 & 10 & 65 & 8 & 15 & 100 \\
20 & 8.6 & 60 & 4.25 & 25 & 65 \\
20 & 4.25 & 65 & 4.25 & 20 & 65 \\
30 & 6.5 & 90 & 6.5 & 10 & 90 \\
18 & 8 & 80 & 8 & 8 & 80 \\
\hline $20.25 \%$ & $8.17 \%$ & $71.25 \%$ & $6.59 \%$ & $16.13 \%$ & $80 \%$ \\
\hline
\end{tabular}

Note. Averages are on the last row. ROE stands for Return on Equity.

\section{The Cash Flows to the Lessor in the Basic Model}

The case study begins by specifying the basic model, and from there undertake simulations on the parameters. The object of interest is to know how much sensitive is the basic model to reasonable changes in the parameters. The underlying model is based on Benninga (2014), and on Brealey et al. (2014). Benninga identifies the cash flows to the leveraged lessor while Brealey et al. insist upon the importance of the investment in working capital. There are four kinds of cash flows: initial flows, periodic flows, working capital flows, and terminal flows. We will envisage each cash flow independently.

The initial cash outflow is the purchase price of the car $(\$ 20,000)$. Care has been taken to sterilize the results from the scale of the initial investment in the car. In other terms the Internal Rate of Return (IRR) is the same for all car prices or scales. But, of course, the Net Present Value (NPV) depends on the scale, and additionally on the selected discount rate. In fact the NPV is directly proportional to the scale. A doubling of the price of the car leads to a doubling of the Net Present Value. This property extends to the whole basic model. Therefore our intent is to calculate the IRR of the project, which is a form of return on equity (ROE) and is comparable to profitability targets.

The second initial cash outflow is the working capital needed to operate the business, and is set to be $\$ 2,000$ ( $10 \%$ of the car purchase price) at the start. The working capital will decay across time but will produce monthly periodic cash inflows (the decrease in working capital). Here the assumption is that the average cash balance should be the half of the change in the working capital. The firm is allowed to extend working capital restrictions by agreeing with the bank a line of credit high enough to cover eventual needs. The rate charged on the utilization of the line of credit is assumed to cost a premium of $2 \%$ for the lessor, over and above the cost of borrowing. Finally there is the borrowed amount from the leveraged purchase of the car which enters as a positive initial cash inflow.

There are two categories of periodic cash flows: cash inflows and cash outflows. The cash inflows consist of the after-tax monthly operating lease amounts that the lessee pays to the lessor. Additionally there is a tax shield from the depreciation expense, which arises because depreciation is not a cash transaction. This tax shield is calculated by multiplying the monthly 
depreciation amount by the tax rate. The tax shield depends therefore on the tax rate, which is assumed to be $20 \%$. Such a figure is in conformity to the actual tax rate imposed by the authorities on the net income from joint-stock companies. In turn the depreciation expense is calculated by assuming a depreciation rate of $10 \%$. Regarding the magnitude of the periodic lease amounts received by the lessor from the lessee, it is computed as an annuity for 36 months at a before-tax rate of $15 \%$. The amount amortized is set to be $40 \%$ of the price of the car, which is approximately the lease term of 3 years over the useful life, which is 10 years.

The periodic cash outflows depend on the maximum financing available from the banking institution for the purchase of the car. This rate is set to be $60 \%$ (see Table 1) which is towards the low level. The borrowing rate for the lessor is set at $8 \%$ (see Table 1) which is towards the high level. The loan, i.e. $60 \%$ of the purchase price of the car, is amortized for 36 monthly periods, i.e. over a total of three years. From the equivalent annuity interest charges are extracted and are taxed. The principal repayments for the annuity are not taxed. This conforms to standard practice. Finally there is a monthly insurance premium against all risks of \$ 50, the annual amount of which represents $3 \%$ of the car purchase price.

The terminal cash flows have to do with the salvage of the car after the three-year expiry of the investment. The basic model assumes that the book and market salvage values are equal. This engenders no tax effects. However if the salvage value, as a proportion of book value, is higher than one, taxes are paid. And if this ratio is less than one a tax credit arises.

With the above assumptions the IRR of the project, i.e. the return on equity stands at $15 \%$ exactly. In Table 1 the ROE selected by the leasing firms are higher than $15 \%$. One should remember that our $15 \%$ is after tax allowances, while the ROE reported by the car leasing companies are probably before tax. It is noteworthy that Lebanese firms pay no or little income taxes, tax evasion being a form of pervasive corruption. In such a case the ROE compiled is indeed before tax also. Anyway, and later, the analysis will consider a higher rate than $15 \%$. By American standards a ROE of $15 \%$ is deemed more than acceptable, in contrast to the market in Lebanon which is cartelized, and where profitability measures turn out to be substantially higher.

\section{The Simulation Results}

The simulations will measure the effect of changing the main parameters of the basic model. The following changes are carried out and their effects measured:

a) Changes in the borrowing amount of the lessor, or in the lessor's credit limit

b) Changes in the leasing or lending rate charged by the lessor to the lessee

c) Changes in the percent of the car purchase that is amortized to the lessee by the lessor. We shall call this change as the recovery of the purchase price

d) Changes in the price of the car

e) Changes in the discount rate in the calculation of the NPV

f) Changes in the initial working capital 
g) Changes in tax rates

h) Changes in the market salvage rate

The sensitivity analysis will be pursued in sequence with the above. In the first analysis the maximum amount from the car purchase price that can be borrowed by the lessor is simulated to vary between 0.50 and 0.95 , by increments of $5 \%$. The scenarios are examined by using the data table command in Excel. In the basic model changing this maximum amount, out of the car purchase price, that can be borrowed by the lessor makes a substantial influence. The basic model assumes a maximum rate of 0.6 . In fact it is precisely 0.60005 , or $60.005 \%$. At this rate the simulated ROE is exactly $15 \%$. Lowering the percent borrowing amount to $55 \%$ produces an IRR, or an ROE, of $11.13 \%$. If the rate is $50 \%$ the ROE is $7.69 \%$. In what follows the ROE and the IRR are interchangeable. Raising the maximum borrowing rate to $65 \%$ produces an ROE of $19.4 \%$. Therefore a rate of $65 \%$ is enough to enable the company to earn its target ROE of $20 \%$. Raising the rate to $70 \%, 75 \%, 80 \%, 85 \%, 90 \%$, and $95 \%$, increases the profitability to $24.51 \%, 30.60 \%, 38.09 \%, 47.82 \%, 61.62 \%$, and $85.32 \%$ respectively. One can conclude that raising the maximum borrowing amount is highly effective in improving the profitability. Not only that but also, and at high leverage levels, the profitability reaches extraordinary and astronomical rates that cannot be readily imagined. It makes a big difference to increase leverage, if this is deemed possible by the lenders to the lessor.

Changes in the leasing or lending rate imposed on the lessee have minimal effects. In the basic model varying this rate from $5 \%$ to $23 \%$, by increments of $1 \%$, changes the ROE by a mere $0.158 \%$. The standard deviation is very low, at $0.05 \%$. At higher leverage ratios produces a higher ROE. For example, with a $75 \%$ borrowing amount the ROE is $30.60 \%$, and with a $95 \%$ borrowing amount the ROE becomes $85.35 \%$. With such an ROE the standard deviation is merely $0.10 \%$. If one compares the simulated ROEs in this section with those in the previous paragraph, it is clearly apparent that the astounding rates of return are due to the maximum borrowing rate and not to the leasing rate. For example, for a given borrowed amount of $95 \%$ the range of values that the IRR takes is between $85.14 \%$ and $85.46 \%$, with a range merely equal to $0.32 \%$. This compares to the average at a $95 \%$ borrowing amount of $85.29 \%$ which is very close to the $85.32 \%$ in the previous paragraph.

The recovery of the car price, as defined above, has also minimal effects. This recovery is simulated to take values between 0.1 and 1 , which is full recovery, with increments of 0.05 . In the basic model the ROE varies between $14.52 \%$ and $15.93 \%$, within a range of $1.41 \%$, and with a standard deviation of $0.44 \%$. At the assumed recovery rate of $40 \%$, increasing the maximum borrowing amount from 0.65 to 0.95 of the value of the car has sizeable repercussions. The ROE varies between $19.40 \%$ and $85.31 \%$. At the mid value of 0.8 the IRR is a $38.09 \%$. Such mid value is extremely reasonable as Table 1 shows. Hence the profitability is very high even at moderate borrowing limits of 0.8. If the firm is faced with borrowing constraints that prevent it from acquiring such a leverage ratio of 0.8 the profitability wanes rapidly, passing from $15 \%$ to $7.69 \%$. Clearly the lessor can multiply its profitability significantly by easing any financial constraints. 
The assumed purchase price of the car in the basic model is $\$ 20,000$. We shall simulate this price by increments of $\$ 2,000$ from a minimum of $\$ 15,000$ to a maximum of $\$ 51,000$. This range encompasses most of the costs of a new car in Lebanon. Although it was pointed above that the model does not change with the scale of the car, nonetheless this price does affect the ROE because we are setting a premium of $2 \%$ on the line of credit used up. Without such a premium, the car cost has no relevance for the calculated ROE. It seems that imposing such a premium carries with it more variation of the ROE than above. For example the range of the ROEs for a credit limit of 0.5 is $2.99 \%$, and this figure grows to reach $3.30 \%$ with a credit limit of 0.95 . The mean value of the ROE varies between $8.69 \%$ with a credit limit of 0.5 , and $86.41 \%$ for the maximum credit limit of 95\%. Expensive cars generate more profits, but these profits are still rather too weak to make a difference.

The assumed discount rate in the basic model is $15 \%$. It will be simulated between $10 \%$ and $19 \%$ by increments of $0.5 \%$. At $15 \%$, the NPV should be close to zero if one does not consider the premium rate on the usage of the line of credit. However if one imposes the premium the NPV is slightly negative at -1.072 . As expected the higher the discount rate the lower is the NPV. With the assumed discount rate of $15 \%$, the NPV is positive only at higher credit limits of 0.65 to 0.95 . The resulting range of the NPVs is around $\$ 7,428$. With credit limits of 0.65 and above, all NPVs are positive whatever the level of the discount rate. The range of NPVs for all credit limits varies little, and takes a value between $\$ 2,364$ and \$2,382. The standard deviations for all credit limits are also very close, ranging between $\$ 738$ and $\$ 744$. If one takes the average value of the NPVs for a credit limit of 0.8 , which is $\$ 4,406$, and if one calculates the equivalent annual annuity at a discount rate of $15 \%$, based on the fact that the project lasts for 3 years, one obtains an annuity amount of \$1,930 approximately. This means that, at these settings, the equity of the firm increases by $\$ 1,930$ indefinitely in the future for each car leased. If the firm is able to get a 95\% financing the average NPV is $\$ 7,590$, corresponding to an equivalent annuity amount at $15 \%$ of $\$ 3,324$. This is quite substantial relative to the underlying level of equity funds.

Working capital is simulated to have increments of \$ 300 from a base of $\$ 500$ to a maximum of $\$ 5,900$. When such changes are imposed the internal profitability of the project deteriorates. The higher the working capital, the higher the implicit cost of this working capital, because funds are recouped later and the time value of money is lost. Hence as working capital increases the IRRs tend to decrease. At the chosen debt financing level (60\%) the range of the IRRs is $8.15 \%$, recording a low of $9.31 \%$ and a high of $17.45 \%$. The ranges of the other cases of financing (from 50\% to 95\%) are similar. Hence the effect of increasing working capital not only reduces the IRR but makes it more dispersed. The standard deviations vary little also from $2.5 \%$ to $2.78 \%$. There is still more embedded dispersion as the grand low is $2.07 \%$, at maximum working capital and lowest debt financing, and the grand high is $88.0 \%$, at maximum debt financing and lowest working capital. While the dispersion is high, the symmetry is not lost: the skewness tests fail to reject the null hypothesis of no skewness for every debt financing level.

Tax rates are modeled to go by a $2 \%$ step from zero to $36 \%$. Although the maximum tax rate is now $25 \%$, we took into consideration the fact that the tax policy may change if the 
authorities choose to do so for the purpose of limiting the explosion of the public debt. Tax evasion is however spread out in Lebanon, and few firms effectively pay taxes. Firms have commonly two accounting books. One is for the tax authorities, and the other is designed for ensuring financing if needed. Evidently, the first will be bleak and the second will be rosy. If one looks across the data table, by increases of debt financing, the ranges within a debt level are small, relatively constant, and have low variability. The ranges hover around $0.1 \%$, from $85.4 \%$ to $85.25 \%$ for example for the highest debt level, and have mostly a variability of $0.03 \%$ to $0.04 \%$. This means that taxation does not affect adversely profitability. On the contrary it seems to have a neutral effect. One could argue that higher taxes produce lower profits, or that higher taxes produce higher tax shields. But the net effect is insignificant. This means that firms in the car leasing industry and in Lebanon should not be wary of changes in tax rates.

In order to ensure the irrelevance of the car price to profitability, I assume that the salvage value changes by percentage points and not by amounts in dollars. A rate of unity means that the book value and the market price, at the end of the three years, are equal. The salvage rate takes values between 0.6 and 1.5 in increments of 0.05 . The results show a very high sensitivity of IRRs to changes in the salvage rate. For example at the base debt financing of 0.6 , the IRR moves from a low of $1.8 \%$ to a high of $26.6 \%$. The only constancy in the simulations is for the variability, as measured by the ranges and standard deviations, within a debt level. The range varies around $25 \%$, and the variability around $8 \%$. One notable feature is that, if the salvage rate is below 0.7, the IRR becomes negative for debt levels of $55 \%$ and $50 \%$. So the grand low is $-5 \%$ and the grand high is approximately $100 \%$ (97.5\%). These results highlight the importance of taking good care of the cars in order for them to fetch higher salvage values. In fact the salvage rate seems to be the most critical in the simulations I have carried out. At the very least if the company aims at keeping the book value close to the market value it can ensure a profitability of $7.7 \%$ and can reach a profitability rate as high as $85 \%$. Fortunately the distribution of IRRs within debt levels is symmetric, the null hypothesis of no skewness failing to be rejected for all debt financing levels.

\section{Conclusion}

We chose to study a case of car leasing for more than one reason. First, it is to build up a model with classic characteristics, based on the inputs that actual car leasing firms use. Second, it is to find out if such a business niche is profitable. Finally, it is to apply the analysis and lay the ground to establish a car leasing venture start-up. Since Lebanon is a highly regarded tourist destination then we should be able to tap and attract tourists in order to lease a car. This is especially critical because Lebanon lacks an efficient public transportation sector.

The results of the simulations indicate that under a proper and affordable financial architecture car leasing is a golden egg in Lebanon. The results are sensitive to two parameters: the borrowing limit and the market salvage value of the car. A high credit limit multiplies the profitability, and a market salvage value higher than book affects the profitability significantly. Other factors have limited effects. For example the results are 
insensitive to the tax rate, which is rather surprising. This means that public policy aimed at raising taxes is neutral on the profitability.

One limitation to the study is the inherent assumption that the car remains leased during the whole term of three years, i.e., the car is never idle at the firm. One avenue for research is to carry out a marketing survey to assess the demand of the market in terms of size and engine power. It should be remembered that, in our case study, the model was constructed in such a way as to produce a limited effect of car price on profitability.

\section{References}

Ang, J., \& Peterson, P. P. (1984). The leasing puzzle. The Journal of Finance, 39(4), 1055-1065. https://doi.org/10.1111/j.1540-6261.1984.tb03892.x

Benninga, S. (2014). Financial Modeling (4th ed.). Cambridge: MIT Press.

Brealey, R. A., Myers, S. C., \& Allen, F. (2014). Principles of Corporate Finance (11th Global ed.). New York: McGraw-Hill.

Copeland, T. E., \& Weston, J. F. (1992). Financial Theory and Corporate Policy (3rd ed.). Boston: Addison-Wesley, Pearson.

Copeland, T. E., Weston, J. F., \& Shastri, K. (2005). Financial Theory and Corporate Policy (4th ed.). Boston: Addison-Wesley, Pearson.

Cosci, S., Guida, R., \& Meliciani, V. (2015). Leasing decisions and credit constraints: Empirical analysis on a sample of Italian firms. European Financial Management, 21(2), 377-398. https://doi.org/10.1111/j.1468-036X.2013.12019.x

Dogan, F. G. (2016). Non-cancellable operating leases and operating leverage. European Financial Management, 22(4), 576-612. https://doi.org/10.1111/eufm.12069

Eisfeldt, A. L., \& Rampini, A. A. (2008). Leasing, ability to repossess, and debt capacity. The Review of Financial Studies, 22(4), 1621-1657. https://doi.org/10.1093/rfs/hhn026

Lasfer, M. A., \& Levis, M. (1998). The determinants of the leasing decision of small and large companies, European Financial Management, 4(2), 159-184. https://doi.org/10.1111/1468-036X.00062

Mannering, F., Winston, C., \& Starkey, W. (2002). An exploratory analysis of automobile leasing by US households. Journal of Urban Economics, 52, 154-176. https://doi.org/10.1016/S0094-1190(02)00009-8

Modigliani, F., \& Miller, M. H. (1958). The cost of capital, corporate finance, and the theory of investment, American Economic Review, 48, 261-297.

Neuberger, D., \& Räthke-Döppner, S. (2013). Leasing by small enterprises. Applied Financial Economics, 23, 535-549. https://doi.org/10.1080/09603107.2012.730132

Ross, S. A., Westerfield, R. W., \& Jaffe, J. (2010). Corporate Finance (9th International ed.). New York: McGraw-Hill. 


\section{Macrothink}

Case Studies in Business and Management

ISSN 2333-3324

2017, Vol. 4, No. 2

Smith, C. W., \& Wakeman, M. (1985). Determinants of corporate leasing policy. The Journal of Finance, 40(3), 895-908. https://doi.org/10.1111/j.1540-6261.1985.tb05016.x

Yan, A. (2006). Leasing and debt financing: Substitutes or complements? Journal of Financial and Quantitative Analysis, 41, 709-731. https://doi.org/10.1017/S0022109000002593

\section{Copyright Disclaimer}

Copyright for this article is retained by the author(s), with first publication rights granted to the journal.

This is an open-access article distributed under the terms and conditions of the Creative Commons Attribution license (http://creativecommons.org/licenses/by/3.0/). 